\title{
Differences in susceptibility of inbred and outbred infant mice to enterotoxigenic Escherichia coli of bovine, porcine and human origin
}

\author{
MARION DUCHET-SUCHAUX, CAROLE LE MAITRE and ANNE BERTIN
}

Institut National de la Recherche Agronomique, Station de Pathologie de la Reproduction, 37380 Nouzilly, France

\begin{abstract}
Summary. Infant mice from outbred Swiss OF1 and from inbred DBA/2, C57BL/6, BALB/cBy and CBA strains were screened for usefulness in the diarrhoea model with enterotoxigenic Escherichia coli (ETEC) strains of bovine, porcine and human origin. Mouse strains were either weakly susceptible or not susceptible to ETEC strains of porcine or human origin bearing antigen $\mathrm{K} 88$, 987P, CFA/I or CFA/II. In contrast, some mouse strains were highly susceptible to bovine and porcine ETEC strains bearing K99 or F41 or both antigens. Swiss OF1 and CBA infant mice were highly susceptible to one bovine ETEC strain bearing antigen K99, whereas DBA/2, BALB/ $\mathrm{cBy}$ and $\mathrm{C} 57 \mathrm{BL} / 6$ mice exhibited nearly complete resistance to the same ETEC strain. Except DBA/2, all mouse strains were highly susceptible to bovine and porcine ETEC strains bearing antigen F41 alone or in combination with antigen $\mathrm{K} 99$. Challenge ETEC strains colonised intestines of all infant mice, but they reached very high levels soon after inoculation in the diarrhoeic ones only.
\end{abstract}

\section{Introduction}

Enterotoxigenic Escherichia coli (ETEC) causes diarrhoea in man and in domestic animals through colonisation of the small intestine and production of enterotoxins. Colonisation of the small intestine is facilitated by surface factors mediating adhesion to the epithelium and usually specific for the host species. Human ETEC strains bear factor CFA/ $\mathrm{I}^{1}$ or CFA/II, ${ }^{2}$ the latter consisting of CS3 associated with CS1 or CS2. ${ }^{3,4}$ Factors $\mathrm{K}^{88^{5,6}}$ and $987 \mathrm{P}^{7,8}$ are specifically expressed in porcine ETEC strains, in contrast to factors $\mathrm{K} 99$ and F41 which are present alone or in combination in bovine ${ }^{9-11}$ and in porcine ${ }^{12,13}$ ETEC strains. ETEC strains can secrete heat-stable or heat-labile enterotoxin or both. ${ }^{14-17}$

We established previously an infant mouse diarrhoea model, by using bovine ETEC strains that bear F41 colonisation factor alone or in combination with factor $\mathrm{K} 99$, and secrete heatstable enterotoxin. ${ }^{18-20}$ Newsome et al. ${ }^{21}$ confirmed our data and they reported additionally the susceptibility of infant mice to porcine strains expressing the same virulence factors and to one bovine strain bearing factor K99 alone. We used our model to study ETEC virulence, ${ }^{19,20}$ and the

Received 17 July 1989; accepted 10 Sept. 1989. protection afforded by vaccination ${ }^{22,23}$ or pharmacological treatments. ${ }^{24}$

Infant mice tested previously appeared not to be susceptible to some CFA/I-positive human strains $^{25}$ or to porcine strains bearing factor K88 or $987 \mathrm{P} .{ }^{19,21}$ The susceptibility of infant mice to bovine ETEC was previously shown to vary according to the mouse strains, ${ }^{18,21}$ suggesting that some of these strains were more useful than others for expression of the illness or for showing resistance to colibacillosis. In an attempt to clarify the response of mouse strains to the same ETEC strain, we have tested the susceptibility of inbred $\mathrm{DBA} / 2$, BALB/cBy, C57BL/6 and CBA mice and of outbred OF1 mice to a panel of ETEC strains of human, bovine and porcine origin, which expressed diverse colonisation factors.

\section{Materials and methods}

\section{Bacterial strains}

$E$. coli strains used for inoculation of infant mice are described in table I. Strains B41, B80 and P2200 were provided as described previously. ${ }^{20,23}$ Strains 1676 and 987 were supplied by Dr H. W. Moon (National Animal Disease Center, Agricultural Research Service, U.S. Department of Agriculture, Ames, Iowa 50010, USA). Strain $\mathrm{H} 10407$ was provided by $\mathrm{Dr}$ A. Andremont 
Table I. ETEC strains used for inoculation of infant mice

\begin{tabular}{|c|c|c|c|c|c|}
\hline $\begin{array}{l}\text { ETEC } \\
\text { strain }\end{array}$ & Serotype & $\begin{array}{l}\text { Colonisation } \\
\text { factors }\end{array}$ & Toxins & $\begin{array}{c}\text { Resistance } \\
\text { to antibiotics* }\end{array}$ & Origin \\
\hline B41 & O101:K99, F41 & K99, F41 & STa & $\mathrm{Sm}, \mathrm{Su}, \mathrm{Tc}$ & Calf \\
\hline B80 & $\mathrm{O} 20: \mathrm{K} 17, \mathrm{~K} 99$ & K99 & STa & $\mathrm{Sm}, \mathrm{Su}, \mathrm{Tc}$ & Calf \\
\hline P2200 & O149:K91, K88ac & K88ac $\dagger$ & STa, LT & $\mathrm{Sm}, \mathrm{Su}, \mathrm{Tc}$ & Piglet \\
\hline 987 & $09: K 103,987 p$ & 987P & STa & $\mathrm{Sm}, \mathrm{Su}$ & Piglet \\
\hline 1676 & O101:K30, F41 & F41 & STa & $\mathrm{Sm}, \mathrm{Su}, \mathrm{Tc}$ & Piglet \\
\hline H10407 & O78:H11 & CFA/I & STa, LT & & Man \\
\hline E4833/76 & $\mathrm{O} 6: \mathrm{H} 16$ & $\mathrm{CS} 2, \mathrm{CS} 3$ & STa, LT & none & Man \\
\hline
\end{tabular}

$\mathrm{STa}=$ heat-stable enterotoxin, tested by the infant mouse test $;{ }^{26} \mathrm{LT}=$ heat-labile enterotoxin.

* Resistance to antibiotics (Sm, streptomycin; Su, sulphadiazine; Tc, tetracycline) was determined with disks (bioMérieux, Marcy l'Etoile, Charbonnières-les-Bains, France) on Mueller-Hinton agar. ${ }^{19}$

$\dagger \mathrm{K} 88 \mathrm{ac}$ is the variant of antigen K88 found on strain P2200.

(Centre Hospitalier Régional Bretonneau, Tours, France). Strain E4833/76 was obtained from Dr B. Rowe (Central Public Health Laboratory, Division of Enteric Pathogens, 61 Colindale Avenue, London NW9 5HT).

\section{Antisera}

Antisera against ETEC strains were prepared in rabbits by multiple intravenous injections of killed bacteria initially, and then live organisms. ${ }^{19}$ The antisera were used unabsorbed.

\section{Animals}

Swiss OF1 mice and inbred strains BALB/cBy (H-2d), C57BL/6 (H-2b), DBA/2 (H-2d) and CBA (H-2k) were obtained from IFFA Credo (Saint Germain-L'Arbresle, France). Animals were raised in an air-conditioned building $\left(21^{\circ} \mathrm{C}\right.$ and $60 \%$ relative humidity), in a room with monitored lighting (light, $12 \mathrm{~h}$; dark, $12 \mathrm{~h}$ ), with free access to sterile food and water. Virgin female mice were mated with males of the same strains at 6-8 weeks of age.

\section{Inoculation of infant mice}

Inoculation was done orally as described previously, ${ }^{18}$ except that pooling and randomisation of mice pups after birth could not be done with inbred strains. The number of infant mice from one litter was limited to eight animals. Bacterial strains were cultured on slopes of Trypticase Soy Agar (TSA; bioMérieux, Marcy l'Etoile, Charbonnières-les-Bains, France) overnight at $37^{\circ} \mathrm{C}$, and cells were harvested in phosphate-buffered saline (PBS), $\mathrm{pH}$ 6.8. Unless otherwise stated, suckling infant mice received orally, at $1 \mathrm{~d}$ of age, $10^{3}$ or $10^{5}$ bacteria of one bacterial strain with a calibrated platinum loop. In one case (ETEC strain B80), infant mice were also inoculated at $3 \mathrm{~d}$ of age. Infected animals were observed daily for $6 \mathrm{~d}$ after inoculation and the mortality was recorded. Manipulation of infant mice at $1 \mathrm{~d}$ of age often resulted in early mortality unrelated to diarrhoea; so, we excluded from analysis litters in which death occurred within $24 \mathrm{~h}$ of inoculation.

\section{Autopsy}

Intestines were removed aseptically from moribund or surviving infant mice 3 and $6 \mathrm{~d}$ after inoculation respectively. Each intestine was weighed, and ground in $2 \mathrm{ml}$ of PBS. The number of lactose-fermenting colonies in the intestinal suspensions was determined by plating serial dilutions in triplicate on Drigalski medium (a thiosulphate medium with lactose and $\mathrm{pH}$ indicators; Institut Pasteur Production, Ville d'Avray, France) with antibiotics (except for ETEC strain E4833/76) and without antibiotics. Antibiotics (SERVA, Heidelberg, West Germany) were sulphadiazine only, $100 \mu \mathrm{g} / \mathrm{ml}$, for ETEC strain H10407, or in combination with streptomycin $2.5 \mu \mathrm{g} / \mathrm{ml}$ for ETEC strain 987 , or with both streptomycin $2.5 \mu \mathrm{g} / \mathrm{ml}$ and tetracycline $16 \mu \mathrm{g} / \mathrm{ml}$ for ETEC strains B41, B80, P2200 and 1676. To ascertain that the recovered bacteria were of the same strain as that inoculated, five lactose-fermenting colonies were isolated from Drigalski medium with and without antibiotics. Each colony was identified serologically by slide agglutination with the appropriate antibacterial serum after subculture on Drigalski medium and on TSA to check for purity. We considered that the challenge ETEC strain was eliminated when isolates from both Drigalski media were negative serologically, or when lactose-fermenting colonies were undetectable on both media. In all other cases except one, the five isolates from Drigalski medium without antibiotics were all positive serologically, and we assumed that all lactose-fermenting colonies consisted of the challenge ETEC strain; consequently, intestinal levels of the inoculated strains were given by the total number of lactose-fermenting colonies. In one case, however, the five isolates from medium without antibiotics were all negative serologically, but those from medium with antibiotics were positive; we therefore calculated the intestinal level of the inoculated 
strain from the number of lactose-fermenting colonies on the medium with antibiotics.

\section{Statistical analysis}

Mortality rates of infant mice were compared by the $\chi^{2}$ test.

\section{Results}

\section{Susceptibility of infant mice to ETEC strains}

Like mouse strain OF1, ${ }^{18}$ strains BALB/cBy, C57BL/6 and CBA presented high mortality rates (table II), $6 \mathrm{~d}$ after inoculation with $10^{3}$ cells of $E$. coli strain B41. In contrast, strain DBA/ 2 was significantly more resistant $(\mathrm{p}<0.001)$. Only mouse strains OF1 and CBA were susceptible to bovine ETEC strain B80 $(\mathrm{K} 99+)$, whereas other mice exhibited almost complete resistance. The high susceptibility of CBA mice to strain B80 was confirmed by the lethality in infant mice inoculated at $3 \mathrm{~d}$ of age, i.e., $15(79 \%)$ of 19 and $21(95 \%)$ of 22 with doses of $10^{3}$ and $10^{5}$ bacteria respectively (data not shown). Among the three porcine strains of ETEC, only strain $1676(\mathrm{~F} 41+)$ induced high levels of mortality. It was highly pathogenic in four of the five strains of mice, but DBA/2 mice were significantly less susceptible $(\mathrm{p}<0.001)$. Although ETEC strain P2200 (K88+) was less pathogenic, there were differences in mouse strain susceptibility: C57BL/6 mice were almost completely resistant whereas DBA/2, BALB/cBy and CBA strains showed mortality rates significantly higher than those reported previously in OF1 mice. ${ }^{19}$ Lastly, all mice were almost completely resistant to ETEC strain $987(987 \mathrm{P}+)$.

Mouse strains were also poorly susceptible to human ETEC strains. Only CBA mice showed much susceptibility to strain $\mathrm{H} 10407$ (CFA/I +), as did $\mathrm{DBA} / 2$ mice and to a less extent $\mathrm{BALB} / \mathrm{cBy}$ mice to strain $\mathrm{E} 4833 / 76(\mathrm{CS} 2+, \mathrm{CS} 3+)$.

Observations $3 \mathrm{~d}$ after challenge with $10^{3}$ bacteria showed further differences in susceptibility of

Table II. Susceptibility of five strains of infant mice to challenge with seven strains of ETEC

\begin{tabular}{|c|c|c|c|c|c|c|c|}
\hline \multirow{2}{*}{$\begin{array}{l}\text { Challenge strain } \\
\text { of ETEC } \\
\text { (colonisation factors) }\end{array}$} & \multirow{2}{*}{$\begin{array}{l}\text { Number of } \\
\text { bacteria } \\
\text { inoculated }\end{array}$} & \multirow{2}{*}{$\begin{array}{l}\text { Period after inocu- } \\
\text { lation (d) }\end{array}$} & \multicolumn{5}{|c|}{$\begin{array}{l}\text { Number of mice }(\%) \text { dead/number inoculated in experiments with } \\
\text { mouse strain }\end{array}$} \\
\hline & & & DBA $/ 2$ & BALB/cBy & C57BL/6 & CBA & OF1 \\
\hline $\begin{array}{l}\text { Bovine strains } \\
\text { B41 (K99, F41) }\end{array}$ & $\begin{array}{l}10^{3} \\
10^{5}\end{array}$ & $\begin{array}{l}3 \\
6 \\
3 \\
6\end{array}$ & $\begin{array}{r}5 / 31(16) \\
7 / 31(23) \\
8 / 38(21) \\
10 / 38(26)\end{array}$ & $\begin{array}{r}4 / 36(11) \\
26 / 36(72) \\
24 / 41(59) \\
35 / 41(85)\end{array}$ & $\begin{array}{c}1 / 20(5) \\
16 / 20(80) \\
13 / 30(43) \\
23 / 30(77)\end{array}$ & $\begin{array}{c}3 / 10(30) \\
8 / 10(80) \\
15 / 16(94) \\
16 / 16(100)\end{array}$ & $\begin{array}{l}41 / 55(75)^{*} \\
68 / 72(94) \\
24 / 24(100)^{*} \\
72 / 72(100)\end{array}$ \\
\hline B80 (K99) & $\begin{array}{l}10^{3} \\
10^{5}\end{array}$ & $\begin{array}{l}3 \\
6 \\
3 \\
6\end{array}$ & $\begin{array}{l}1 / 21(5) \\
1 / 21(5) \\
0 / 15(0) \\
0 / 15(0)\end{array}$ & $\begin{array}{c}2 / 26(8) \\
2 / 26(8) \\
10 / 62(16) \\
10 / 62(16)\end{array}$ & $\begin{array}{l}0 / 14(0) \\
0 / 14(0) \\
0 / 26(0) \\
0 / 26(0)\end{array}$ & $\begin{array}{c}6 / 12(50) \\
11 / 12(92) \\
\text { ND } \\
\text { ND }\end{array}$ & $\begin{array}{l}11 / 47(23) \\
29 / 47(62) \\
31 / 48(65) \\
32 / 48(67)\end{array}$ \\
\hline $\begin{array}{l}\text { Porcine strains } \\
1676(\mathrm{~F} 41)\end{array}$ & $\begin{array}{l}10^{3} \\
10^{5}\end{array}$ & $\begin{array}{l}3 \\
6 \\
3 \\
6\end{array}$ & $\begin{array}{c}1 / 17(6) \\
4 / 17(23) \\
9 / 31(29) \\
22 / 31(71)\end{array}$ & $\begin{array}{l}7 / 38(18) \\
34 / 38(89) \\
32 / 52(62) \\
50 / 52(96)\end{array}$ & $\begin{array}{l}13 / 22(59) \\
21 / 22(96) \\
31 / 37(83) \\
36 / 37(97)\end{array}$ & $\begin{array}{r}5 / 13(39) \\
8 / 13(62) \\
18 / 23(78) \\
22 / 23(96)\end{array}$ & $\begin{array}{l}23 / 24(96) \\
24 / 24(100) \\
24 / 24(100) \\
24 / 24(100)\end{array}$ \\
\hline $\mathrm{P} 2200(\mathrm{~K} 88)$ & $\begin{array}{l}10^{3} \\
10^{5}\end{array}$ & $\begin{array}{l}6 \\
6\end{array}$ & $\begin{array}{l}2 / 20(10) \\
9 / 24(38)\end{array}$ & $\begin{array}{l}3 / 21(14) \\
8 / 25(32)\end{array}$ & $\begin{array}{l}1 / 22(5) \\
0 / 26(0)\end{array}$ & $\begin{array}{l}6 / 17(35) \\
5 / 22(23)\end{array}$ & $\begin{array}{l}1 / 48(2) \dagger \\
9 / 72(12) \dagger\end{array}$ \\
\hline 987 (987P) & $\begin{array}{l}10^{3} \\
10^{5}\end{array}$ & $\begin{array}{l}6 \\
6\end{array}$ & $\begin{array}{l}1 / 21(5) \\
1 / 23(4)\end{array}$ & $\begin{array}{l}0 / 30(0) \\
3 / 32(9)\end{array}$ & $\begin{array}{l}2 / 31(7) \\
3 / 34(9)\end{array}$ & $\begin{array}{l}2 / 18(11) \\
3 / 29(10)\end{array}$ & $\begin{array}{l}1 / 24(4) \\
0 / 24(0)\end{array}$ \\
\hline $\begin{array}{l}\text { Human strains } \\
\text { H10407 (CFA/I) }\end{array}$ & $\begin{array}{l}10^{3} \\
10^{5}\end{array}$ & $\begin{array}{l}6 \\
6\end{array}$ & $\begin{array}{l}1 / 21(5) \\
3 / 27(11)\end{array}$ & $\begin{array}{l}0 / 29(0) \\
5 / 31(16)\end{array}$ & $\begin{array}{l}2 / 34(6) \\
9 / 43(21)\end{array}$ & $\begin{array}{r}7 / 19(37) \\
10 / 24(42)\end{array}$ & $\begin{array}{l}0 / 24(0) \\
0 / 24(0)\end{array}$ \\
\hline $\mathrm{E} 4833 / 76(\mathrm{CS} 2, \mathrm{CS} 3)$ & $\begin{array}{l}10^{3} \\
10^{5}\end{array}$ & $\begin{array}{l}6 \\
6\end{array}$ & $\begin{array}{r}6 / 35(17) \\
15 / 33(46)\end{array}$ & $\begin{array}{c}2 / 46(4) \\
14 / 53(26)\end{array}$ & $\begin{array}{l}0 / 36(0) \\
3 / 28(11)\end{array}$ & $\begin{array}{l}0 / 54(0) \\
1 / 30(3)\end{array}$ & $\begin{array}{c}\text { ND } \\
0 / 32(0)\end{array}$ \\
\hline
\end{tabular}

ND $=$ Not done.

- Data from previous study. ${ }^{18}$

$\dagger$ Data from previous study. ${ }^{19}$ 
mouse strains to ETEC strains B41, B80 and 1676. Indeed, at this time, mortality rates of OF1 mice challenged with ETEC strains B41 and 1676 were significantly higher $(p<0.001)$ than in all other mouse strains. In the same way, CBA mice died more quickly than OF 1 mice after inoculation with ETEC strain B80, even when they were infected at $3 \mathrm{~d}$ of age : mortality rates were $10(53 \%)$ of $19(\mathrm{p}<$ $0.05)$ and $21(95 \%)$ of $22(\mathrm{p}<0.01)$ after inoculation with $10^{3}$ and $10^{5}$ bacteria respectively.

Generally, the use of $10^{5}$ bacteria instead of $10^{3}$ induced earlier mortality, but did not significantly increase the mortality rates $6 \mathrm{~d}$ after challenge (except in DBA/2 and CBA mice inoculated with ETEC strain 1676). Thus, results obtained with an inoculum of $10^{5}$ organisms confirmed the susceptibility or resistance of mouse strains to ETEC.

\section{Intestinal colonisation by ETEC strains}

High levels of the ETEC strains $\left(10^{8}-10^{9} / \mathrm{g}\right)$ were observed in the intestines of diarrhoeic infant mice, $3 \mathrm{~d}$ after inoculation (table III). Although colony counts of lactose-fermenting bacteria resistant to antibiotics were always lower than the total counts (not shown), all isolates from Drigalski medium without antibiotics were identified as the challenge strain. These results showed predominance of the challenge strain in the intestine and suggest that diarrhoea was induced by intense intestinal multiplication of the challenge ETEC strain.
Most animals that survived $6 \mathrm{~d}$ after inoculation had total intestinal lactose-fermenting colonies consisting only of the challenge ETEC strain (table III). For one given ETEC strain, intestinal levels were very similar in all strains of mice. All ETEC strains had similar levels of colonisation, whatever the strain of mice inoculated. Fourteen of the 85 healthy animals did not show the challenge ETEC strain in the total or the antibiotic-resistant lactosefermenting colonies. Therefore, they probably eliminated the challenge strain from their intestine. Elimination occurred more often in CBA mice than in other mouse strains, and was most frequent with ETEC strain 987 (table III).

\section{Discussion}

In the present study, we failed to find mouse strains highly susceptible to porcine and human ETEC strains bearing K88, 987P, CFA/I and CFA/ II colonisation factors. In contrast, we showed that some mouse strains were resistant to ETEC strains of bovine or porcine origin bearing factor K99 or F41 or both. Generally, every challenge ETEC strain colonised the intestine of infant mice, but in susceptible animals they reached very high levels as soon as $3 \mathrm{~d}$ after inoculation. The existence of mouse strains that are highly susceptible or completely resistant to the same ETEC strain suggests that expression of the illness could be genetically controlled, as described previously in piglets in-

Table III. Intestinal colonisation of four strains of infant mice by seven challenge strains of ETEC

\begin{tabular}{|c|c|c|c|c|}
\hline \multirow{2}{*}{$\begin{array}{l}\text { Challenge } \\
\text { strain of } \\
\text { ETEC }\end{array}$} & \multicolumn{4}{|c|}{$\begin{array}{c}\log _{10} \text { of mean count and SD of challenge strain recorded per } \mathrm{g} \text { of intestine* after oral inoculation } \\
\text { of mouse strain }\end{array}$} \\
\hline & DBA $/ 2$ & $\mathrm{BALB} / \mathrm{cBy}$ & $\mathrm{C} 57 \mathrm{BL} / 6$ & CBA \\
\hline \multicolumn{5}{|c|}{ Diarrhoeic mice } \\
\hline B41 & $8.25(1 / 1) \dagger$ & $8 \cdot 15 \mathrm{SD} 0.60(2 / 2)$ & 8.57 SD $0.64(3 / 3)$ & $8.08 \mathrm{SD}_{1} .02(3 / 3)$ \\
\hline B80 & $(0 / 0)$ & $(0 / 0)$ & $(0 / 0)$ & $9.02 \mathrm{SD} 0 \cdot 15(3 / 3)$ \\
\hline 1676 & $(0 / 0)$ & 8.84 SD $0.90(3 / 3)$ & $(0 / 0)$ & $(0 / 0)$ \\
\hline P2200 & $8.13 \mathrm{SD} 0.09(3 / 3)$ & $\ldots \quad(0 / 0)$ & $(0 / 0)$ & $(0 / 0)$ \\
\hline \multicolumn{5}{|c|}{ Non-diarrhoeic mice } \\
\hline B80 & $6.70 \mathrm{SD} 0.99(4 / 5)$ & $7.23 \mathrm{SD} 0.42(5 / 5)$ & $7.80 \mathrm{SD} 0.84(5 / 5)$ & 6.85 \\
\hline 1676 & 7.33 SD $0.47(3 / 3)$ & 6.49 SD $0.01(3 / 3)$ & $7 \cdot 39$ SD $0.02(2 / 2)$ & $7 \cdot 86$ \\
\hline P2200 & $7 \cdot 32$ SD $0.33(3 / 3)$ & $7 \cdot 33$ SD $0.65(3 / 3)$ & 7.52 SD $0.62(3 / 3)$ & 7.24 SD $0.64(2 / 3)$ \\
\hline 987 & $7 \cdot 39$ SD $0.60(2 / 5)$ & 6.74 SD $0.39(5 / 5)$ & 6.88 SD $0.92(4 / 5)$ & $(1 / 5)$ \\
\hline $\mathrm{H} 10407$ & $7.84 \mathrm{SD} 0.34(3 / 3)$ & 7.74 SD $0.32(3 / 3)$ & 8.01 SD $0.64(3 / 3)$ & 7.74 SD $0.03(3 / 3)$ \\
\hline $\mathrm{E} 4833 / 76$ & 7.52 SD $0.36(3 / 3)$ & $6.93 \mathrm{SD} 0.67(3 / 3)$ & $7.03 \mathrm{SD} 0.44(3 / 3)$ & 6.69 SD $0.89(3 / 3)$ \\
\hline
\end{tabular}

* Mean number of lactose-fermenting colonies which were the same as the challenge strain serologically (see Materials and methods).

$\dagger$ In parenthesis: the number of animals showing only the challenge ETEC strain in the lactose-fermenting colonies tested/the number of animals examined at autopsy. 
fected with K88-positive ETEC strains. ${ }^{27}$ Moreover, the mouse model appears suitable for studying mechanisms involved in the expression of susceptibility or resistance to ETEC strains.

We did not observe mouse strains that were resistant or susceptible to every ETEC strain tested. However, DBA/2 mice were resistant to almost all ETEC strains, whereas CBA mice were generally susceptible. Susceptibility patterns of OF1 mice to ETEC strains bearing factors K88, 987P, K99 and F41 were similar to those described in MF1 mice by Newsome et al. ${ }^{21}$ However, MF1 mice appeared less susceptible than OF1 mice to strains bearing K99 or F41 or both of these factors. This difference may be because the MF1 mice were inoculated at the age of $4 \mathrm{~d}$ compared with $1 \mathrm{~d}$ in the present study. We have indeed showed that susceptibility decreases significantly from the age of $3 \mathrm{~d} .{ }^{18}$ Newsome et al. ${ }^{21}$ found differences in susceptibility of three mouse strains to one bovine ETEC strain bearing both K99 and F41 factors. They attributed these differences to environmental factors. In the present study, we have observed more striking differences, especially with ETEC strain B80 bearing factor K99 alone. Environmental factors such as those described by Newsome et al. probably did not interfere in the present study because every mouse strain originated from the same supplier and mice were mated and raised in rigorously standardised conditions. Another potential source of bias could have been an intercurrent rotavirus infection. ${ }^{28}$ We did not investigate this possibility, but we think that in such an occurrence every mouse strain would have been equally contaminated.

In the present study, it appears that at least one mouse strain presented some susceptibility to each ETEC strain (except with ETEC strain 987), even when the ETEC strains were weakly virulent. This result suggests that other mouse strains could exist that are highly susceptible to ETEC strains bearing factors $\mathrm{K} 88$, 987P, CFA/I or CFA/II. For instance, Davidson and Hirsh ${ }^{29}$ reported that one K88positive strain induced diarrhoea in CF1 mice.

Susceptibility patterns of mouse strains differed according to the ETEC strain. Therefore, if genetic control of resistance occurs, the mechanism would hypothetically involve factor(s) specific for ETEC strains, i.e., colonisation factors, enterotoxins or other unknown factors. There is an apparent contradiction between the successful colonisation

\section{REFERENCES}

1. Evans D G, Silver R P, Evans D J, Chase D G, Gorbach S L. Plasmid-controlled colonization factor associated of resistant animals by ETEC strains and a postulated mechanism of susceptibility directed specifically toward a colonisation factor, such as that demonstrated in piglets with ETEC strains bearing antigen $\mathrm{K} 88 .{ }^{27}$ However, colonisation factors probably favoured intense proliferation of ETEC strains necessary to the expression of diarrhoea. Thus, we observed previously ${ }^{20}$ that variants of strain B41, which failed to express K99 and F41 but still secreted STa toxin were no longer pathogenic or were much less so than the parental strain in OF1 infant mice. As in OF1 mice ${ }^{30}$ and MF1 mice ${ }^{21}$ intestinal levels of $E$. coli were abnormally high in diarrhoeic infant mice $3 \mathrm{~d}$ after inoculation, compared with those of non-inoculated normal mice. ${ }^{31}$ In contrast, the $E$. coli intestinal population was similar in animals at $7 \mathrm{~d}$ of age, either inoculated or not. ${ }^{31}$ Previous reports also showed the ability of some ETEC strains bearing factors $\mathrm{K} 99{ }^{32-34} \mathrm{~K} 88{ }^{32} 987 \mathrm{P}^{21}$ or $\mathrm{CFA} / \mathrm{I}^{25}$ to colonise the intestine of infant mice, but they did not mention any pathogenic effect. Diarrhoea was evidently determined by intestinal levels of ETEC strains rather than mere colonisation. It appears surprising that an inoculum of $10^{5}$ bacteria, compared with $10^{3}$, induced only earlier mortality, without increasing final mortality rates. ETEC strains probably reached pathological intestinal levels more quickly in susceptible animals inoculated with $10^{5}$ bacteria, but this dose was not enough to make ETEC strains virulent in resistant animals.

In conclusion, this study presents a new application of the infant mouse model, by allowing analysis of mechanisms involved in resistance or susceptibility to colibacillosis. Indeed, genetic aspects could be studied by testing susceptibility of $F 1$ (resistant $x$ susceptible) infant mice and of parental backcrosses. The role of colonisation factors, enterotoxins or other bacterial factors in the expression of disease could also be investigated to elucidate physio-pathological mechanisms of susceptibility to colibacillosis.

This work was supported by grant 4835 "Génétique de l'hôte et résistance aux maladies infectieuses et parasitaires" from Institut National de la Recherche Agronomique. We are grateful to Drs A. Andremont, H. W. Moon and B. Rowe for kindly supplying ETEC strains; to H. Le Roux and E. Rabouan for excellent assistance in animal production and care; and to J. De Rycke for English corrections.

with virulence in Escherichia coli enterotoxigenic for humans. Infect Immun 1975; 12: 656-667.

2. Evans D G, Evans D J. New surface-associated heat-labile colonization factor antigen (CFA/II) produced by 
enterotoxigenic Escherichia coli of serogroups O6 and O8. Infect Immun 1978; 21 : 638-647.

3. Cravioto A, Scotland S M, Rowe B. Hemagglutination activity and colonization factor antigens I and II in enterotoxigenic and non-enterotoxigenic strains of Escherichia coli isolated from humans. Infect Immun 1982; 36: 189-197.

4. Smyth C J. Two mannose-resistant haemagglutinins on enterotoxigenic Escherichia coli of serotype O6:K15:H16 or $\mathrm{H}$ - isolated from travellers' and infantile diarrhoea. J Gen Microbiol 1982; 128: 20812096.

5. Stirm S, Ørskov F, Ørskov I, Birch-Andersen A. Episomecarried surface antigen K88 of Escherichia coli. III Morphology. J Bacteriol 1967; 93: 740-748.

6. Jones $G$ W, Rutter J M. Role of the K88 antigen in the pathogenesis of neonatal diarrhea caused by Escherichia coli in piglets. Infect Immun 1972; 6: 918-927.

7. Isaacson R E, Nagy B, Moon H W. Colonization of porcine small intestine by Escherichia coli: colonization and adhesion factors of pig enteropathogens that lack K88. $J$ Infect Dis 1977; 135: 531-539.

8. Nagy B, Moon H W, Isaacson R E. Colonization of porcine intestine by enterotoxigenic Escherichia coli: selection of piliated forms in vivo, adhesion of piliated forms to epithelial cells in vitro, and incidence of a pilus antigen among porcine enteropathogenic $E$. coli. Infect Immun $1977 ; 16: 344-352$.

9. Ørskov I, Ørskov F, Smith H, Sojka W J. The establishment of K99, a thermolabile, transmissible Escherichia coli $\mathrm{K}$ antigen, previously called "Kco", possessed by calf and lamb enteropathogenic strains. Acta Pathol Microbiol Scand [B] 1975; 83: 31-36.

10. De Graaf F K, Roorda I. Production, purification and characterization of the fimbrial adhesive antigen F41 isolated from calf enteropathogenic Escherichia coli strain B41 M. Infect Immun 1982; 36: 751-758.

11. Morris J A, Thorns C, Scott A C, Sojka W J, Wells G A. Adhesion in vitro and in vivo associated with an adhesive antigen (F41) produced by a K99 mutant of the reference strain Escherichia coli B41. Infect Immun 1982; 36: 1146-1153.

12. Moon H W, Nagy B, Isaacson R E, Ørskov I. Occurrence of $\mathrm{K} 99$ antigen on Escherichia coli isolated from pigs and colonization of pig ileum by $\mathrm{K} 99+$ enterotoxigenic E. coli from calves and pigs. Infect Immun 1977; 15: 614-620.

13. Morris J A, Thorns C J, Wells G A H, Scott A C, Sojka W J. The production of F41 fimbriae by piglet strains of enterotoxigenic Escherichia coli that lack K88, K99 and 987P fimbriae. J Gen Microbiol 1983; 129: 2753-2759.

14. Smith $\mathrm{H} \mathrm{W}$, Halls $S$. The transmissible nature of the genetic factor in Escherichia coli that controls haemolysin production. J Gen Microbiol 1967; 47: 153-161.

15. Smith $\mathbf{H} \mathbf{W}$, Linggood $\mathbf{M} \mathbf{A}$. The transmissible nature of enterotoxin production in a human enteropathogenic strain of Escherichia coli. J Med Microbiol 1971 ; 4: 301305.

16. Smith $\mathbf{H ~ W , ~ L i n g g o o d ~} \mathbf{M}$ A. Further observations on Escherichia coli enterotoxins with particular regard to those produced by atypical piglet strains and by calf and lamb strains: the transmissible nature of these enterotoxins and $\mathrm{K}$ antigen possessed by calf and lamb strains. J Med Microbiol 1972; 5: 243-250.

17. Gyles C, So M, Falkow S. The enterotoxin plasmids of Escherichia coli. J Infect Dis 1974; 130 : 40-49.

18. Duchet-Suchaux M. Le souriceau, modèle d'étude de la diarrhée colibacillaire. Ann Microbiol (Inst. Pasteur) 1980; 131B: 239-250.

19. Bertin A. Virulence factors of enterotoxigenic $E$. coli studied in the infant mouse model. Ann Rech Vét 1983; 14: $169-182$.

20. Bertin A. F41 antigen as a virulence factor in the infant mouse model of Escherichia coli diarrhoea. J Gen Microbiol 1985 ; 131 : 3037-3045.

21. Newsome $\mathbf{P}$ M, Burgess $M$ N, Burgess $M$ R, Coney $K$ A, Goddard M E, Morris J A. A model of acute infectious neonatal diarrhoea. J Med Microbiol 1987; 23 : 19-28.

22. Duchet-Suchaux M. Infant mouse model of $E$. coli diarrhea clinical protection induced by vaccination of the mothers. Ann Rech Vét 1983; 14: 319-331.

23. Duchet-Suchaux M. Protective antigens against enterotoxigenic Escherichia coli O101:K99, F41 in the infant mouse diarrhea model. Infect Immun 1988; 56: 13641370.

24. Bertin A. Chlorpromazine and propranolol extend survival of infant mice inoculated with enterotoxigenic Escherichia coli. Ann Rech Vét 1981; 12: 137-141.

25. Goldhar J, Zilberberg A, Ofek I. Infant mouse model of adherence and colonization of intestinal tissues by enterotoxigenic strains of Escherichia coli isolated from humans. Infect Immun 1986; 52 : 205-208.

26. Dean A G, Ching Y C, Williams R G, Harden L B. Test for Escherichia coli enterotoxin using infant mice: application in a study of diarrhea in children in Honolulu. $J$ Infect Dis 1972; 125: 407-411.

27. Rutter J M, Burrows M R, Sellwood R, Gibbons R A. A genetic basis for resistance to enteric disease caused by E. coli. Nature 1975; 257 : 135-136.

28. Newsome $\mathbf{P} \mathbf{M}$, Coney $\mathbf{K}$ A. Synergistic rotavirus and Escherichia coli diarrheal infection of mice. Infect Immun $1985 ;$ 47: 573-574.

29. Davidson J N, Hirsh D C. Use of the K88 antigen for in vivo bacterial competition with porcine strains of enteropathogenic Escherichia coli. Infect Immun 1975; 12: 134-136.

30. Duchet-Suchaux M. Modèle d'étude de la diarrhée colibacillaire chez le souriceau nouveau-né. In : J. F. Desjeux, R. Ducluzeau (eds) La diarrhée du jeune. INSERM, Paris. 1984: 443-454.

31. Moreau M C, Raibaud P, Muller M C. Relation entre le développement du système immunitaire intestinal à IgA et l'établissement de la flore microbienne dans le tube digestif du souriceau holoxénique. Ann Immunol (Inst. Pasteur) 1982; 133D : 29-39.

32. Kétyi I, Kuch B, Vertényi A. Stability of Escherichia coli adhesive factors K88 and $\mathrm{K} 99$ in mice. Acta Microbiol Acad Sci Hung 1978; 25: 77-86.

33. Moon H W, Fung P Y, Isaacson R E, Booth G D. Effects of age, ambient temperature, and heat-stable Escherichia coli enterotoxin on intestinal transit in infant mice. Infect Immun 1979; 25: 127-132.

34. Nagy B, Ushe T C. Colonization of infant mice by K99+ Escherichia coli and lack of colonization by Streptococcus faecium M74. Acta Vet Hung 1985; 33 : 143-147. 